\title{
Serum Resistance in Riemerella anatipestifer is Associated with Systemic Disease in Ducks
}

\author{
Bai Wei ${ }^{1}$, Hye-Suk Seo ${ }^{1}$, Ke Shang ${ }^{1}$, Jun-feng Zhang ${ }^{2}$, Jong-Yeol Park ${ }^{3}$, Yea-Jin Lee ${ }^{3}$, Yu-ri Choi ${ }^{3}$, \\ Sang-Won $\mathrm{Kim}^{3}$, Se-Yeoun $\mathrm{Cha}^{4}$, Hyung-Kwan $\mathrm{Jang}^{4}$ and Min $\mathrm{Kang}^{4+}$ \\ ${ }^{I}$ Doctor, Department of Veterinary Infectious Diseases and Avian Diseases, College of Veterinary Medicine and Center for \\ Poultry Diseases Control, Jeonbuk National University, Iksan 54596, Republic of Korea \\ ${ }^{2}$ Graduate Student, Department of Veterinary Infectious Diseases and Avian Diseases, College of Veterinary Medicine and Center for \\ Poultry Diseases Control, Jeonbuk National University, Iksan 54596, Republic of Korea \\ ${ }^{3}$ Graduate Student, Department of Veterinary Infectious Diseases and Avian Diseases, College of Veterinary Medicine and Center for \\ Poultry Diseases Control, Jeonbuk National University, Iksan 54596, Republic of Korea \\ ${ }^{4}$ Professor, Department of Veterinary Infectious Diseases and Avian Diseases, College of Veterinary Medicine and Center for \\ Poultry Diseases Control, Jeonbuk National University, Iksan 54596, Republic of Korea
}

\begin{abstract}
Riemerella anatipestifer (RA) can cause septicemia, polyserositis, and ataxia in ducks. It can also colonize the upper respiratory tract of healthy ducks. These differences in pathogenicity are probably the result of diverse mechanisms of virulence in different strains. Since serum resistance is a feature frequently found in systemic pathogens, 130 RA strains having different clinical origins were tested. A variety of serum susceptibility levels were detected. Pharynx strains from healthy ducks were mainly susceptible to the bactericidal effect of the serum, while systemic strains were serum resistant. Heat-treatment of the sera abolished the bactericidal activity, indicating that complement is a key factor in this effect. In an attempt to associate serum-resistance to surface determinant genes of the bacteria, we screened for six genes involved in lipopolysaccharide synthesis and membrane proteins in RA. Of these, three genes (AS87_09335, AS87_00480, and AS87_05195) encoding outer membrane proteins might be implicated in serum resistance statistically. The results indicate that serum resistance is a virulence mechanism in RA.
\end{abstract}

(Key words: Riemerella anatipestifer, duck, serum resistance, virulence gene)

\section{INTRODUCTION}

Riemerella anatipestifer (RA) is a gram-negative, nonmotile, non-spore forming, rod-shaped bacterium that causes systemic disease in ducks that is characterized by fibrinous polyserositis, arthritis, and meningitis, sometimes with caseous salpingitis and vegetative disorder (Sandhu, 1997). The disease can also feature greenish diarrhea, pyrexia, anorexia, growth retardation, nasal discharge, coughing, restlessness, polydipsia, ataxia, hypermetria, weakness, tremors, and limb swelling (Ryll et al., 2001; Sandhu and Harry, 1981). High mortality and weight loss by virulent isolates result in major economic losses globally, especially to the duck industry (Sarver et al., 2005; Liu et al., 2013).

Twenty-one RA serotypes have been identified. Significant cross-reactions among serotypes have not been reported (Pathanasophon et al., 2002). For a clear laboratory diagnosis of RA disease, systemic samples from ducks showing clinical lesions are required (Wang et al., 2012). Thus, swabs from the meninges, pericardium, air sac, peritoneum, liver, oviduct, and joints, or alternatively, fluids from the corresponding affected cavities, are the samples of choice for diagnosis (Sandhu, 1997). However, RA can persist on the pharyngeal mucous membranes of clinically healthy ducks (Ryll et al., 2001). In addition to the production of different pathological conditions, differing degrees of virulence of RA have been demonstrated (Ryll et al., 2001; Wang et al., 2012). However, the virulence mechanisms are unknown.

The ability of bacteria to produce systemic infection often corresponds to resistance to the bactericidal activity of complement (Rautemaa and Meri, 1999), allowing bacteria to survive in the bloodstream and reach internal organs where they develop their pathological effect. Serum resistance has not been studied in RA. However, since this bacterium can

${ }^{\dagger}$ To whom correspondence should be addressed : vet.minkang@gmail.com 
cause a systemic infection, it may play a role in virulence. To test this hypothesis, we studied the serum resistance of RA isolates from different clinical outcomes. In addition, previous studies reported that complement resistance is associated with factors including capsules, lipopolysaccharide (LPS), and outer membrane proteins (OMPs) (Álvarez et al., 2000; Attia et al., 2005; Hallström et al., 2006; Hansen and Hirsh, 1989; Marques et al., 1992). Therefore, we determined the correlation between serum resistance and these genes in RA.

\section{MATERIALS AND METHODS}

\section{Bacterial Strains and Growth Conditions}

A total of 130 strains were used. They included isolates from systemic infection $(n=30)$ and normal pharynx $(n=100)$. The pharyngeal isolates were obtained from healthy ducks that were in flocks on disease-free farms during 2002 and 2015. The systemic isolates were isolated from the internal organs of ducks involved in RA outbreaks occurring on duck farms during 2012 and 2015. The samples were smeared on Columbia blood agar base (Becton, Dickinson and Company, Franklin Lakes, NJ, USA) containing 5\% sheep blood with 6 $\mathrm{mg} / \mathrm{mL}$ neomycin sulfate and $20 \mathrm{mg} / \mathrm{mL}$ gentamycin sulfate (Sigma-Aldrich, Saint Louis, MO, USA) as described previously (Rubbenstroth et al., 2013). After incubation at $37^{\circ} \mathrm{C}$ in a $5 \% \mathrm{CO}_{2}$ incubator for $36 \mathrm{~h}$, suspect RA colonies with typical morphological characteristics were sub-cultured on $5 \%$ sheep blood agar (Hanil Komed, Seung-nam, South Korea). RA was identified by morphology and PCR as described previously (Qu et al., 2006). The forward primer 190f (5'-GTATTGAAAGCTCTGGCGG-3') and reverse primer 843r (5'-TCGCTTAGTCTCTGAACCC-3') were used to amplify a 654 base pair (bp) covering the 16S rDNA region (190-843). All strains were stored in $20 \%$ glycerol-Brain HeartI nfusion at $-70^{\circ} \mathrm{C}$ until use.

\section{Serotyping}

The 130 RA field isolates were serotyped against 16 serotypes by the agar gel precipitin test (AGP) and slide agglutination (SA) test as previously described (Pathanasophon et al., 2002; Rubbenstroth et al., 2013). Ten reference strains including serotype 1 (D-24105), 3 (D-26338), 4 (H-2565), 5 (D-24123), 6 (P-2123), 7 (D-27179), 14 (D-664), 17 (K-1499), 19 (30/90), and $21(1062 / 91)$ were provided from the South Korea Animal and Plant Quarantine Agency. Six serotypes of commercial anti-RA sera (Biovac, Angers, France) were applied to the RA field isolates for serotyping by the SA test against serotypes 2, 11, 12 (cross-reactive with 16), 13, and 18 .

\section{Serum Resistance Assay}

Complement-mediated serum resistance assay was performed for the 130 isolates. Normal duck sera were collected from eight 21-day-old healthy Pekin ducks. The sera were pooled and filter-sterilized $(0.22 \mu \mathrm{m})$ and were confirmed to be negative for RA antibody using a previously described ELISA analysis (Higgins et al., 2000). Normal duck sera resistance assay was performed as previously described (Cerda-Cuellar and Aragon, 2008) with some modifications. Briefly, $180 \mu \mathrm{L}$ of either untreated sera (NS) or heat-inactivated sera (HS) were added to wells of a multi-well plate. Twenty microliter aliquots of bacterial suspension $\left(1.0 \times 10^{8} \mathrm{CFU} / \mathrm{mL}\right)$ were separately dispensed in each well. The mixtures were incubated at $37^{\circ} \mathrm{C}$ for $2 \mathrm{~h}$, serially diluted 10 -fold, and plated on 5\% sheep blood agar. The plates were incubated at $37^{\circ} \mathrm{C}$ with $5 \% \mathrm{CO}_{2}$ for $36 \mathrm{~h}$ for bacterial counting. The logarithmic reduction of bacterial counts was calculated $(\log [\mathrm{CFU} / \mathrm{mL}$ in $\mathrm{HS}]-\log [\mathrm{CFU} / \mathrm{mL}$ in NS]) as previously described (Cerda-Cuellar and Aragon, 2008). A strain showing a reduction of $<1 \log$ was considered resistant. Each strain was tested three times.

\section{PCR Amplification for Detection of Outer Membrane and LPS Synthesis Associated Genes}

Total DNA of the isolates was extracted from freshly cultured cells by the freezing and boiling method. In brief, cells were resuspended in $100 \mu \mathrm{L}$ of sterile deionized water, frozen at $-80^{\circ} \mathrm{C}$ for $10 \mathrm{~min}$, and then boiled at $100^{\circ} \mathrm{C}$ for 15 $\min$. Samples were centrifuged at $16,000 \times g$ for $10 \mathrm{~min}$ and the supernatant was stored at $-40^{\circ} \mathrm{C}$ until assayed. Four RA outer membrane genes (AS87_09335, AS87_05195, AS87_00480 and $O m p A)$ and two RA LPS synthesis-associated genes (AS8704050 and AS87 01015) were selected from the 
previously identified genes (Hu et al., 2011; Wang et al., 2014; Wang et al., 2015). The presence of AS87_09335, AS87_00480, AS87_05195, AS87_04050, AS87_01015, and OmpA genes were confirmed for the 130 isolates by PCR. The primers and GenBank accession numbers are listed in Table 1. Amplification was performed by pre-denaturation at $94^{\circ} \mathrm{C}$ for $1 \mathrm{~min} ; 35$ cycles of denaturation at $94^{\circ} \mathrm{C}$ for $1 \mathrm{~min}$, annealing at $54-65^{\circ} \mathrm{C}$ for $1 \mathrm{~min}$, and extension at $72^{\circ} \mathrm{C}$ for $1 \mathrm{~min}$; and a final extension step of $5 \mathrm{~min}$ at $72^{\circ} \mathrm{C}$.

\section{Statistical Analysis}

All data were analyzed using SPSS v. 12.0 software (SPSS, Chicago, IL, USA). The Student's $t$-test and Chi-square test was used for univariate analysis of the significance of associations. Differences were considered statistically significant at a $P$-value $<0.05$.

\section{RESULTS}

\section{Serotype Distribution of Field RA Isolates}

The 130 isolates were examined against 16 serotypes. Of these, 107 of the isolates matched 13 known serotypes $(1,2$, $4,5,6,7,11,13,14,17,18,19$, and 21) with the remaining 23 isolates being non-typable (Table 2). The most frequent serotypes were $1(15.3 \%), 11(11.9 \%)$, and 2 (8.9\%), followed by multiple serotype 4, 17, 18, and 21 (8.9\%), 13 $(7.4 \%)$, and $6(5.2 \%)$. Isolation sites according to the serotypes were analyzed. Serotypes 1, 2, 5, 6, 7, and 11 were associated with clinical isolates. Serotypes 13, 14, 17, and 19 and the multiple serotypes including $4,13,14,17,18$, and 21 were only found in pharyngeal isolates.

\section{Serum Resistance}

Duck serum had a different effect on RA strains with different clinical backgrounds. Fig. 1(a) depicts the effect of duck serum on the 130 RA strains from the pharynx and systemic sites. Susceptibility to serum varied widely. The strains isolated from systemic sites from ducks with fibrinous polyserositis were highly resistant to duck serum (Fig. 1(a)). These isolates had serum resistant which showed less than reduction of 1 Log CFU. Almost all pharyngeal strains from disease-free farms were serum-sensitive. Almost all pharyngeal strains from disease-free farms were serum-susceptible (Fig. 1(b) and 1(c)). However, four strains (D14-3, D14-5, D14-RDA-2, D15-RDA-129) were resistant. These strains shared a common geographical origin (Chungbuk), but there was no evident explanation for the serum resistance of these strains obtained from a healthy background. Systemic strains were significantly more serum resistant than pharynx strains $(P<0.05$, Student's $t$-test) (Fig. 1(a)). A different level of

Table 1. Primers used for the detection of outer membrane and LPS synthesis-associated genes in $R$. anatipestifer

\begin{tabular}{|c|c|c|c|c|c|c|c|}
\hline Genes & Location & Description of genes & Primer sequence $\left(5^{\prime}-3^{\prime}\right)$ & $\begin{array}{l}\text { Size } \\
\text { (bp) }\end{array}$ & $\begin{array}{l}\text { Annealing } \\
\text { temperature }\end{array}$ & $\begin{array}{l}\text { Accession } \\
\text { no. }\end{array}$ & Source \\
\hline AS87_09335 & $\begin{array}{c}\text { Outer } \\
\text { membrane }\end{array}$ & Membrane protein & $\begin{array}{l}\text { F: GGACTGCTTTACCTTTGTCTG } \\
\text { R: ATACTGGTCTTTGGCACGC }\end{array}$ & 1174 & $60^{\circ} \mathrm{C}$ & $\begin{array}{c}\mathrm{NZ} \_\mathrm{CP} 00720 \\
4.1\end{array}$ & $\begin{array}{l}\text { This } \\
\text { study }\end{array}$ \\
\hline AS87_05195 & $\begin{array}{c}\text { Outer } \\
\text { membrane }\end{array}$ & Hypothetical protein & $\begin{array}{l}\text { F: ATTGACATTATGCGTCGTGG } \\
\text { R: TGCCGTCTGAACCTTGAAA }\end{array}$ & 774 & $55^{\circ} \mathrm{C}$ & $\begin{array}{c}\mathrm{NZ}+\mathrm{CP} 00720 \\
4.1\end{array}$ & $\begin{array}{l}\text { This } \\
\text { study }\end{array}$ \\
\hline AS87_00480 & $\begin{array}{c}\text { Outer } \\
\text { membrane }\end{array}$ & Hypothetical protein & $\begin{array}{l}\text { F: ACCACAAAGGTAACCCAAGA } \\
\text { R: TGTCCTGAAGTCTCCGCTA }\end{array}$ & 1180 & $60^{\circ} \mathrm{C}$ & $\begin{array}{c}\mathrm{NZ}+\mathrm{CP} 00720 \\
4.1\end{array}$ & $\begin{array}{l}\text { This } \\
\text { study }\end{array}$ \\
\hline AS87_04050 & $\begin{array}{l}\text { Cytoplasmic } \\
\text { membrane }\end{array}$ & $\begin{array}{c}\text { Vi polysaccharide } \\
\text { biosynthesis protein } \\
\text { VipB/TviC }\end{array}$ & $\begin{array}{l}\text { F: CCGCTCGAGATGAATAACAGGAAAA } \\
\text { TATTAATTACTGGAGGGGCAGG } \\
\text { R: CATGCATGCTTATTTCAACCTCTTCC } \\
\text { AATACCAATCCAC }\end{array}$ & 972 & $65^{\circ} \mathrm{C}$ & $\begin{array}{c}\mathrm{NZ} C \mathrm{CP} 00720 \\
4.1\end{array}$ & $\begin{array}{l}\text { Wang et } \\
\text { al., } 2014\end{array}$ \\
\hline AS87_01015 & $\begin{array}{l}\text { Cytoplasmic } \\
\text { membrane }\end{array}$ & $\begin{array}{c}\text { Glycosyl transferase } \\
\text { family } 2\end{array}$ & $\begin{array}{l}\text { F: AATCTTCATTTCACCAGCCG } \\
\text { R: TTATCCCAACCCAATACGGA }\end{array}$ & 328 & $55^{\circ} \mathrm{C}$ & $\begin{array}{c}\mathrm{NZ} \_\mathrm{CP} 00720 \\
4.1\end{array}$ & $\begin{array}{l}\text { This } \\
\text { study }\end{array}$ \\
\hline OmpA & $\begin{array}{l}\text { Outer } \\
\text { membrane }\end{array}$ & $\begin{array}{l}\text { Outer membrane } \\
\text { protein }\end{array}$ & $\begin{array}{l}\text { F: ATGTTGATGACTGGACTTGGTCT } \\
\text { R: CTTCACTACTGGAAGGTCAGACTT }\end{array}$ & 1119 & $54^{\circ} \mathrm{C}$ & AF104936.1 & $\begin{array}{l}\text { Yu et al., } \\
2008\end{array}$ \\
\hline
\end{tabular}


Table 2. Serotype distribution of R. anatipestifer isolates in South Korea between 2002 and 2015

\begin{tabular}{|c|c|c|c|}
\hline \multirow{2}{*}{ Serotype } & \multicolumn{2}{|c|}{ Isolation site } & \multirow{2}{*}{ No. of isolates (\%) } \\
\hline & Pharynx & Systemic & \\
\hline 1 & 18 & 2 & $20(15.3)$ \\
\hline 2 & 1 & 11 & $12(8.9)$ \\
\hline 2,17 & 2 & 0 & $2(1.5)$ \\
\hline $2,4,17,18,21$ & 2 & 0 & $2(1.5)$ \\
\hline 4,21 & 4 & 0 & $4(3.0)$ \\
\hline $4,13,14$ & 2 & 0 & $2(1.5)$ \\
\hline $4,13,21$ & 6 & 0 & $6(4.4)$ \\
\hline $4,17,18,21$ & 12 & 0 & $12(8.9)$ \\
\hline 5 & 0 & 1 & $1(0.7)$ \\
\hline 6 & 0 & 7 & $7(5.2)$ \\
\hline 7 & 0 & 1 & $1(0.7)$ \\
\hline 11 & 8 & 8 & $16(11.9)$ \\
\hline $11,17,18$ & 1 & 0 & $1(0.7)$ \\
\hline 13 & 10 & 0 & $10(7.4)$ \\
\hline 13,14 & 1 & 0 & $1(0.7)$ \\
\hline $13,18,21$ & 1 & 0 & $1(0.7)$ \\
\hline 14 & 3 & 0 & $3(2.3)$ \\
\hline 17 & 1 & 0 & $1(0.7)$ \\
\hline 19 & 5 & 0 & $5(3.7)$ \\
\hline Non-typable & 23 & 0 & $23(17.7)$ \\
\hline Total & 100 & 30 & $130(100.0)$ \\
\hline
\end{tabular}

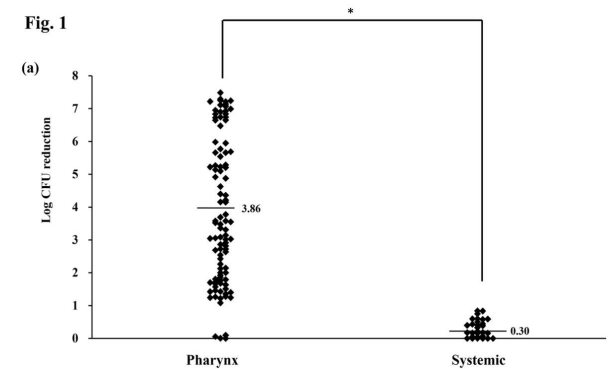

(a)

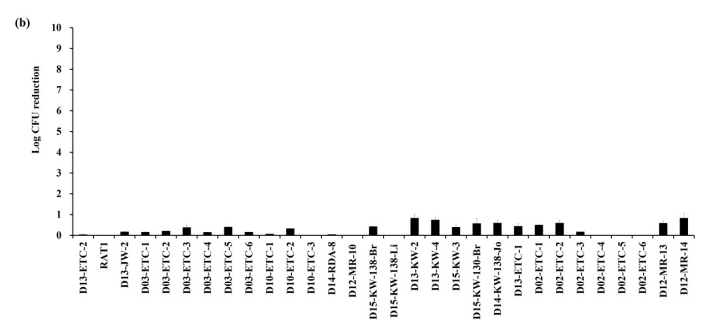

(b)

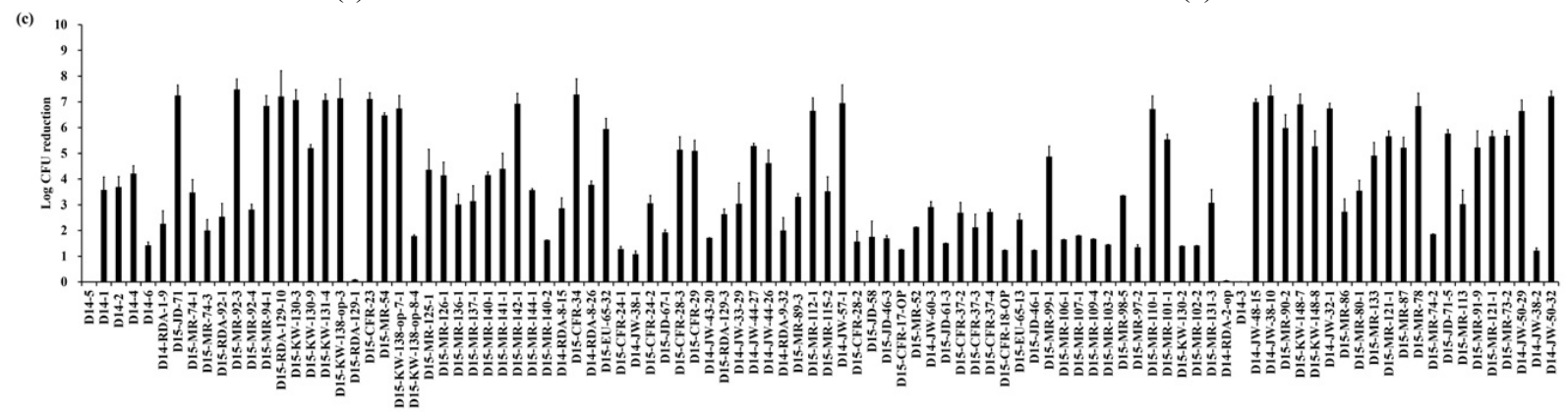

(c)

Fig. 1. Susceptibility of $R$. anatipestifer field strains to duck serum. Logarithmic reduction of CFU after treatment of bacteria with normal duck serum is plotted by groups based on isolation site (a) or by individual strains (b and c). In (a), the difference in serum susceptibility between the pharynx group and the systemic strain group was significant $(P=0.011$; Student's $t$-test). In (b) and (c), bars represent the mean \pm standard deviation of the results found in three experiments in systemic strains (b) and pharynx strains (c). 
Table 3. Correlation between serum resistance and virulence of $\mathrm{R}$. anatipestifer isolates

\begin{tabular}{ccccc}
\hline \hline \multirow{2}{*}{ Isolation site } & No. of isolates & \multicolumn{2}{c}{ Serum reaction $^{1}$} & Probability (\%) $^{2}$ \\
\cline { 3 - 5 } Pharynx & 100 & SR & SS & 4.0 \\
Internal organs $(\mathrm{n}=30)$ & 30 & 4 & 96 & 100 \\
\hline Total $(\mathrm{n}=130)$ & 130 & 34 & 96 & 26.2 \\
\hline
\end{tabular}

${ }^{1} \mathrm{SR}$, serum resistant isolates; SS, serum susceptible isolates.

2. Probability of serum resistance.

serum sensitivity according to the isolation site of isolates was confirmed and an extremely strong correlation between serum resistance and clinical isolates (systemic) was observed (Table 3).

\section{Association between Serum Resistance and Gene Presence}

We analyzed the outer membrane and LPS synthesisassociated genes in RA strains from different clinical backgrounds to investigate the correlation between the presence of these genes and serum resistance (Table 4). All systemic isolates were positive for AS87_09335, AS87_00480, AS87_04050, AS87_01015, and OmpA, but only $46.7 \%$ were positive for AS87_05195. Almost all (93\%) of the strains positive for AS87_05195 belonged to serotype 1 and 2. Comparison of the isolates obtained from systemically infected and healthy birds revealed significant differences in the infected birds in the distributions of AS87_09335, AS87_00480, AS87_05195, and AS87_04050. No comparative differences were evident for AS87_01015 and OmpA. A highly significant association with serum resistance was confirmed for four genes: AS87_09335, AS87_05195, AS87_00480, and AS87_04050 (P<0.05). AS87_09335 was present in all 34 isolates that were resistant to serum but in only $7(7.3 \%)$ of 96 isolates that were susceptible to serum. This was the strongest association among the 6 genes, and was followed by AS87_00480, AS87_05195, AS87_04050, AS87_01015, and OmpA. AS87_00480, AS87_05195, and AS87_04050 were confirmed in $31(91.2 \%), 17(50.0 \%)$, and $31(91.2 \%)$ of 34 isolates resistant to serum, respectively, and were identified from 25 (26.0\%), 7 (7.3\%) and $17(17.7 \%)$ of 96 isolates susceptible to serum, respectively. Lack of significant association to

Table 4. Correlation between serum resistance and gene presence in $R$. anatipestifer isolates

\begin{tabular}{|c|c|c|c|c|c|c|}
\hline \multirow{2}{*}{ Genes } & \multicolumn{3}{|c|}{$\mathrm{SR}^{1}(\mathrm{n}=34)$} & \multicolumn{3}{|c|}{$\mathrm{SS}^{1}(\mathrm{n}=96)$} \\
\hline & $+^{2}$ & -2 & Frequency $(\%)^{3}$ & $t^{2}$ & -2 & Frequency $(\%)^{3}$ \\
\hline AS87_09335 & 34 & 0 & $100.0^{4}$ & 7 & 89 & 7.3 \\
\hline AS87_00480 & 31 & 3 & $91.2^{4}$ & 25 & 71 & 26.0 \\
\hline AS87_05195 & 17 & 17 & $50.0^{4}$ & 7 & 89 & 7.3 \\
\hline AS87_04050 & 31 & 3 & $91.2^{4}$ & 17 & 79 & 17.7 \\
\hline AS87_01015 & 32 & 2 & 94.1 & 91 & 5 & 94.8 \\
\hline OmpA & 34 & 0 & 100.0 & 92 & 4 & 95.8 \\
\hline
\end{tabular}

${ }^{1} \mathrm{SR}$, serum resistant isolates; SS, serum susceptible isolates.

${ }^{2}+$, no. of isolates with gene; -, no. of isolates without gene.

${ }^{3}$ Frequency of gene (\%).

${ }^{4}$ Significant correlation between serum resistance and gene presence (Chi-square test, $P<0.05$ ) or Significantly higher frequency in SR than SS (Chi-square test, $P<0.05$ ). 
serum resistance was observed in $A S 8701015$ and $O m p A$ genes, respectively.

\section{DISCUSSION}

Different strains of RA display varying degrees of virulence (Sandhu, 1991). However, the proposed determinants of virulence of this bacterium have not been fully demonstrated. Since some strains of RA can produce systemic disease (duck septicemia), we decided to study the role of serum resistance in the virulence of RA.

Complement in the bloodstream is one host defense mechanism against gram-negative bacteria. Bacteria cell membrane lysis is induced by the formation of a membrane attack complex (Tizard, 2013). Serum resistance is associated with systemic disease by gram-negative bacteria including Pasteurella multocida, Escherichia coli, and Aeromonas hydrophila (Snipes and Hirsh, 1986; Morishita et al., 1990; Leung et al., 1995; Mellata et al., 2003), and serum resistance assays have been used to statistically assess virulence. This has been observed in other bacteria such as Haemophilus parasuis (Pai and DeStephano, 1982; Cerda-Cuellar and Aragon, 2008). Cerda'-Cue'llar and Aragon (2008) showed that serum resistance is associated with systemic infection of $H$. parasuis by demonstrating that nasal strains from healthy piglets were susceptible to the bactericidal effect of the serum, while the systemic strains leading to systemic disease were usually resistant to serum. Our results showed that pharynx strains isolated from healthy ducks from septicemia-free farms were most susceptible to serum (Fig. 1). This observation may indicate the lack of an invasion potential of these strains. When the pharynx isolates were analyzed, two separate groups were detected: serum-susceptible and -resistant isolates. The highly virulent isolates, RAT1, D10-ETC-1, and D03-ETC-1 which showed $>80 \%$ mortality in ducks demonstrated highly resistant to duck serum. The highly virulent isolates, RAT1, D10-ETC-1, and D03-ETC-1 which showed $>80 \%$ mortality in ducks demonstrated highly resistant to duck serum. The moderate virulent isolates, D13-KW-2, D13-ETC-1, and D02-ETC-1 which result in $60.0 \%$ mortality in ducks showed between 0.44 and 0.83 which is relatively lower resistance than that of the highly virulent isolates. On the other hand, avirulent isolates, D12-WB-3, D11-WB-226, D14-1, D14-RDA-1-9, and D15-CFR-17-Br showed no mortality in ducks and were serum sensitive. Interestingly, the serum-resistant pharynx strains were isolated from the pharynx of ducks lacking systemic lesions, which may be a potential cause of future clinical lesions, because serum resistance may indicate the ability of these strains to invade and produce systemic infection. On the other hand, all of the systemic isolates were serum resistant, suggesting that this ability is necessary for the spread of the bacteria to internal organs and for the production of systemic disease. Therefore, our results suggest that serum resistance is a mechanism involved in the virulence of RA, which seems to comprise serum-susceptible pharynx strains not associated with disease production (non-virulent strains) and systemic strains (virulent and invasive strains).

With some bacterial pathogens, serum resistance is associated with surface structures, such as capsule, surface proteins, or LPS (Hansen and Hirsh, 1989; Marques et al., 1992; Rautemaa and Meri, 1999; Álvarez et al., 2000; Attia et al., 2005; Hallström et al., 2006), which hinder the access of complement components to the bacterial membrane, and membrane proteins that interfere with membrane attack by activated complement (Montenegro et al., 1985; Rautemaa and Meri, 1999). In one study, an acapsular mutant constructed by disrupting the hexA gene was no longer resistant to normal chicken serum, while the wild-type strain was resistant, which suggests that serum resistance is correlated with the possession of a capsule (Chung et al., 2001). Serum resistance by LPS and K1 capsule are pathogenic mechanisms of APEC, with a strong correlation demonstrated between serum resistance and virulence (Mellata et al., 2003). The Iss and TraT genes in E. coli are associated with resistance to serum (Binns et al., 1979; Chuba et al., 1986). We conducted and compared 6 genes involved in LPS synthesis and membrane proteins using RA isolates with or without serum resistance. Three genes (AS87_09335, AS87_00480, and AS87_05195) that encode outer membrane proteins were implicated in the serum resistance of RA. The authors of the study confirmed that these genes were predicted to be outer membrane 
proteins (Wang et al., 2015). AS87_09335 is involved in transport processes and encodes an outer membrane protein designated TonB-dependent receptor. TonB-dependent receptors combine with an extracellular or intracellular messenger and transmit the messenger into or out of the cytoplasm, leading to the transcriptional activation of target genes (Koebnik, 2005). The TonB protein of E. coli carries out high-affinity binding and energy-dependent uptake of specific substrates into the periplasmic space (Chimento et al., 2003). Proteins currently known to act as TonB-dependent receptors include HpuAB, ShuA, lactoferrin-binding protein (Lbp), and transferrin-binding protein (Tbp) (Rohde et al., 2002; Ekins et al., 2004). Furthermore, TonB-dependent receptor TbdR1 has been identified as a cross-immunogenic antigen among RA serotypes 1, 2, and 10 (Hu et al., 2012a). The TonB-dependent receptor TdrA of Pseudomonas fluorescens, which is a protective immunogen, is likely required for iron acquisition and optimal bacterial virulence ( $\mathrm{Hu}$ et al., 2012b). We speculate that the products of AS87_09335 may play a similar role in the pathogenicity of RA.

However, the specific function of the AS87_00480 and AS87_05195 encoded hypothetical proteins remain speculative. Although there was a statistical association between genes linked to outer membrane proteins and serum resistance, we do not have an explanation for the discrepancy in which some pharynx strains with serum susceptibility possessed these genes. Further studies will be required to elucidate the function of these genes. In addition, the variety in the level of serum resistance could be an indication of the existence of more than one mechanism involved in RA pathogenicity. These possible mechanisms would act jointly in the highly serum-resistant strains.

In conclusion, serum-resistance seems to play a role in the virulence of RA, although further studies are needed to determine the specific mechanism(s) involved.

\section{적 요}

리메렐라 아나티페스티퍼 감염증은 오리와 거위에서 섬 유소성 심막염, 간주위염증, 기낭염, 건락성난관염, 뇌막염 을 특징으로 하는 급성 또는 만성 패혈증이다. 이 균은 혈청
형 또는 분리주별로 병원성에 큰 차이가 나타나는 것으로 알려져 있다. 그럼에도 불구하고 지금까지 이러한 다양한 병원성과 그 이유에 대한 연구는 거의 이루어지지 않았다. 본 연구에서는 리메렐라 아나티페스티퍼의 병원성과 serum resistance 상관성을 구명하였다. 우리는 다양한 분리원으로 부터 확보한 130 주의 균주를 대상으로 serum resistance 특 성을 분석하였다. 건강한 오리 인후두에서 분리된 균주들은 혈청에 대한 감수성이 높은 반면에 전신감염을 일으킨 균주 들은 강한 serum resistance를 보였다. 또한 우리는 이러한 혈청의 살균효과가 혈청내 보체 성분에 의해 유도됨을 확인 하였다. 강한 serum resistance를 유발하는 세균의 표면 유전 자와의 관련성을 조사한 결과, 외막 단백질의 AS87_09335, AS87_00480,AS87_05195 유전자가 serum resistance와 관련 있음을 알 수 있었다. 본 연구 결과로 serum resistance 특성 이 리메렐라 아나티페스티퍼의 병원성 결정 요소 중 하나라 는 것을 확인하였다.

\section{ACKNOWLEDGMENTS}

This work was supported by Korea Institute of Planning and Evaluation for Technology in Food, Agriculture, Forestry and Fisheries (716002-7), South Korea.

\section{ORCID}

$\begin{array}{ll}\text { Bai Wei } & \text { https://orcid.org/0000-0003-1169-2500 } \\ \text { Hye-Suk Seo } & \text { https://orcid.org/0000-0003-1175-2139 } \\ \text { Ke Shang } & \text { https://orcid.org/0000-0001-5617-2168 } \\ \text { Jun-Feng Zhang } & \text { https://orcid.org/0000-0003-2360-6382 } \\ \text { Jong-Yeol Park } & \text { https://orcid.org/0000-0002-5389-6387 } \\ \text { Yea-Jin Lee } & \text { https://orcid.org/0000-0003-0193-9039 } \\ \text { Yu-Ri Choi } & \text { https://orcid.org/0000-0002-6913-087X } \\ \text { Sang-Won Kim } & \text { https://orcid.org/0000-0002-4738-0341 } \\ \text { Se-Yeoun Cha } & \text { https://orcid.org/0000-0001-5745-4845 } \\ \text { Hyung-Kwan Jang } & \text { https://orcid.org/0000-0003-3542-3620 } \\ \text { Min Kang } & \text { https://orcid.org/0000-0001-5650-1144 }\end{array}$

\section{REFERENCES}

Álvarez D, Merino S, Tomás JM, Benedí VJ, Albertí S 2000 Capsular polysaccharide is a major complement resistance 
factor in lipopolysaccharide O side chain-deficient Klebsiella pneumoniae clinical isolates. Infect Immun 68(2):953-955.

Attia AS, Lafontaine ER, Latimer JL, Aebi C, Syrogiannopoulos GA, Hansen EJ 2005. The UspA2 protein of Moraxella catarrhalis is directly involved in the expression of serum resistance. Infect Immun 73(4):2400-2410.

Binns M, Davies D, Hardy K 1979 Cloned fragments of the plasmid ColV, I-K94 specifying virulence and serum resistance. Nature 279(5716):778-781.

Cerda-Cuellar M, Aragon V 2008 Serum-resistance in Haemophilus parasuis is associated with systemic disease in swine. Vet J 175(3):384-389.

Chimento DP, Kadner RJ, Wiener MC 2003 The Escherichia coli outer membrane cobalamin transporter BtuB: structural analysis of calcium and substrate binding, and identification of orthologous transporters by sequence/structure conservation. J Mol Biol 332(5):999-1014.

Chuba PJ, Palchaudhuri S, Leon MA 1986 Contributions of traT and iss genes to the serum resistance phenotype of plasmid ColV2-K94. FEMS Microbiol Lett 37(2):135-140.

Chung JY, Wilkie I, Boyce JD, Townsend KM, Frost AJ, Ghoddusi M, Adler B 2001 Role of capsule in the pathogenesis of fowl cholera caused by Pasteurella multocida serogroup A. Infect Immun 69(4):2487-2492.

Ekins A, Khan AG, Shouldice SR, Schryvers AB 2004 Lactoferrin receptors in gram-negative bacteria: insights into the iron acquisition process. Biometals 17(3):235-243.

Hallström T, Trajkovska E, Forsgren A, Riesbeck K 2006 Haemophilus influenzae surface fibrils contribute to serum resistance by interacting with vitronectin. J Immunol 177(1):430-436.

Hansen LM, Hirsh DC 1989 Serum resistance is correlated with encapsulation of avian strains of Pasteurella multocida. Vet Micro 21(2):177-184.

Higgins DA, Henry RR, Kounev ZV 2000 Duck immune responses to Riemerella anatipestifer vaccines. Dev Comp Immunol 24(2-3):153-167.

Hu Q, Ding C, Tu J, Wang X, Han X, Duan Y, Yu S 2012a Immunoproteomics analysis of whole cell bacterial proteins of Riemerella anatipestifer. Vet Micro 157(3-4):428-438.

Hu Q, Han X, Zhou X, Ding C, Zhu Y, Yu S 2011 OmpA is a virulence factor of Riemerella anatipestifer. Vet
Micro 150(3-4):278-283.

Hu YH, Dang W, Sun L 2012b A TonB-dependent outer membrane receptor of Pseudomonas fluorescens: virulence and vaccine potential. Arch Microbiol 194(9):795-802.

Koebnik R 2005 TonB-dependent trans-envelope signalling: the exception or the rule? Trends Microbiol 13(8):343-347.

Leung K, Yeap I, Lam T, Sin Y 1995 Serum resistance as a good indicator for virulence in Aeromonas hydrophila strains isolated from diseased fish in South East Asia. J Fish Dis 18(6):511-518.

Liu H, Wang X, Ding C, Han X, Cheng A, Wang S, Yu S 2013 Development and evaluation of a trivalent Riemerella anatipestifer-inactivated vaccine. Clin Vaccine Immunol 20(5):691-697.

Marques MB, Kasper D, Pangburn M, Wessels M 1992 Prevention of $\mathrm{C} 3$ deposition by capsular polysaccharide is a virulence mechanism of type III group B streptococci. Infect Immun 60(10):3986-3993.

Mellata M, Dho-Moulin M, Dozois CM, Curtiss III R, Brown PK, Arné P, Brée A, Desautels C, Fairbrother JM 2003 Role of virulence factors in resistance of avian pathogenic Escherichia coli to serum and in pathogenicity. Infect Immun 71(1):536-540.

Montenegro M, Bitter-Suermann D, Timmis J, Agüero M, Cabello F, Sanyal S, Timmis K 1985 traT gene sequences, serum resistance and pathogenicity-related factors in clinical isolates of Escherichia coli and other gramnegative bacteria. Microbiology 131(6):1511-1521.

Morishita TY, Snipes KP, Carpenter TE 1990 Serum resistance as an indicator of virulence of Pasteurella multocida for turkeys. Avian Dis 34:888-892.

Pai CH, DeStephano L 1982 Serum resistance associated with virulence in Yersinia enterocolitica. Infect Immun 35(2):605-611.

Pathanasophon P, Phuektes P, Tanticharoenyos T, Narongsak W, Sawada T 2002 A potential new serotype of Riemerella anatipestifer isolated from ducks in Thailand. Avian Pathol 31(3):267-270.

Qu F, Cai C, Zheng X, Zhang D 2006 Rapid identification of Riemerella anatipestifer on the basis of specific PCR amplifying 16S rDNA. Wei Sheng Wu Xue Bao 46(1):13-17.

Rautemaa R, Meri S 1999 Complement-resistance mechanisms of bacteria. Microbes Infect 1(10):785-794. 
Rohde K, Gillaspy A, Hatfield M, Lewis L, Dyer D 2002 Interactions of haemoglobin with the Neisseria meningitidis receptor $\mathrm{HpuAB}$ : the role of $\mathrm{TonB}$ and an intact proton motive force. Mol Microbiol 43(2):335-354.

Rubbenstroth D, Ryll M, Knobloch JK-M, Köhler B, Rautenschlein S 2013 Evaluation of different diagnostic tools for the detection and identification of Riemerella anatipestifer. Avian Pathol 42(1):17-26.

Ryll M, Christensen H, Bisgaard M, Christensen JP, Hinz KH, Köhler B 2001 Studies on the prevalence of Riemerella anatipestifer in the upper respiratory tract of clinically healthy ducklings and characterization of untypable strains. J Vet Med B 48(7):537-546.

Sandhu T, Harry E 1981 Serotypes of Pasteurella anatipestifer isolated from commercial White Pekin ducks in the United States. Avian Dis 25:497-502.

Sandhu TS 1991 Immunogenicity and safety of a live Pasteurella anatipestifer vaccine in White Pekin ducklings: laboratory and field trials. Avian Pathol 20(3):423-432.

Sandhu TS, Rimler RB 1997 Riemerella anatipestifer Infection. Iowa State University Press, Pages 758-764.

Sarver CF, Morishita TY, Nersessian B 2005 The effect of route of inoculation and challenge dosage on Riemerella anatipestifer infection in Pekin ducks (Anas platyrhynchos). Avian Dis 49(1):104-107.

Snipes KP, Hirsh DC 1986 Association of complement sensitivity with virulence of Pasteurella multocida isolated from turkeys. Avian Dis 30:500-504.

Tizard, I.R., 2013. Veterinary Immunology. Elsevier Health Sciences.

Wang X, Ding C, Wang S, Han X, Hou W, Yue J, Zou J, Yu S 2014 The AS87_04050 gene is involved in bacterial lipopolysaccharide biosynthesis and pathogenicity of Riemerella anatipestifer. PLOS ONE 9(10):e109962.

Wang X, Ding C, Wang S, Han X, Yu S 2015 Whole-genome sequence analysis and genome-wide virulence gene identification of Riemerella anatipestifer strain $\mathrm{Yb} 2$. Appl Environ Microb 81(15):5093-5102.

Wang XP, Zhu DK, Wang MS, Cheng AC, Jia RY, Chen S, Chen XY, Tang T 2012 Development and application of specific polymerase chain reaction assay targeting the gyrB gene for rapid detection of Riemerella anatipestifer. Poult Sci 91(10):2450-2453.

Received Nov. 8, 2021, Revised Dec. 28, 2021, Accepted Dec. 29, 2021 
